\title{
Depression of Ventilation by Dopamine in Man
}

\author{
EVIDENCE FOR AN EFFECT ON THE CHEMORECEPTOR REFLEX
}

\author{
Michael J. Welsh, Donald D. Heistad, and Francois M. Abboud, Cardiovascular \\ Division and the Department of Internal Medicine, Cardiovascular Center, \\ University of Iowa College of Medicine; and the Veterans Administration \\ Hospital, Iowa City, Iowa 52242
}

\begin{abstract}
A B S T R A C T Dopamine is present in the carotid body and has been postulated to be an inhibitory neurotransmitter. The purpose of this study was to determine the effects of dopamine on ventilation in man and to examine its mechanism of action. Dopamine (0.5-10 $\mu \mathrm{g} / \mathrm{kg}$ per min) was infused in eight normal men at different levels of arterial chemoreceptor activity, produced by varying the inspired $\mathrm{PO}_{2}$. During normoxia dopamine produced a small decrease in minute ventilation $(\dot{V} E)$ and an increase in arterial $\mathrm{PCO}_{2}$. When arterial chemoreceptors were stimulated by hypoxia, infusion of dopamine produced a marked initial depression of $\dot{V} E$ followed by a sustained although less pronounced decrease in $\dot{V}$. An increase in $\mathrm{PA}_{\mathrm{CO}_{2}}$ and a decrease in $\mathrm{PaO}_{2}$ were also observed. When arterial chemoreceptor activity was suppressed by hyperoxia, infusion of dopamine did not affect ventilation. Subjects also breathed a hypercarbic, hyperoxic gas mixture. The hypercarbia produces hyperventilation by stimulating central chemoreceptors, whereas the hyperoxia suppresses peripheral chemoreceptors. Dopamine did not alter ventilation while the subjects were breathing this gas mixture.
\end{abstract}

These studies suggest that dopamine suppresses ventilation in man through an action on the arterial chemoreceptor reflex. These findings support the hypothesis that dopamine is an inhibitory neurotransmitter in the carotid body, and that release of dopamine may modulate the sensitivity of peripheral arterial chemoreceptors.

\section{INTRODUCTION}

The carotid body chemoreceptors are important regulators of ventilation in man (1). Dopamine and other catecholamines have been found in the carotid body of man and animals (2-7) and it has been proposed that the re-

Received for publication 27 June 1977 and in revised form 30 September 1977. lease of dopamine in the carotid body may suppress the sensitivity of the chemoreceptor nerve endings $(8-11)$.

Physiologic studies of the function of dopamine in the carotid body have been performed in the cat and dog. In the cat dopamine produces a decrease in carotid body neural output and a depression of ventilation $(12,13)$. However, in the dog dopamine has been reported to stimulate ventilation $(12,14)$. In light of this species difference, it is important to determine the effect of dopamine on ventilation in man. There are no studies that have examined the role of dopamine in modulation of the arterial chemoreceptor reflex in man.

The present experiments were done to test the hypothesis that dopamine inhibits the chemoreceptor reflex and depresses ventilation in man. We postulated that the depression of ventilation by dopamine might be related to the level of chemoreceptor activity. Therefore, dopamine was infused intravenously while subjects breathed: room air; hypoxic gas mixtures, during which chemoreceptor activity is increased; and $100 \%$ oxygen, which suppresses arterial chemoreceptor activity (15).

In addition, responses were observed while subjects breathed hypercarbic hyperoxic gas mixtures. Hypercarbia produces hyperventilation by stimulation of central medullary chemoreceptors (16), and hyperoxia suppresses the activity of peripheral arterial chemoreceptors (15). We postulated that if the effect of dopamine were mediated through depression of the peripheral chemoreceptor reflex, the infusion of dopamine to subjects breathing this gas mixture would not alter ventilation. On the other hand, if the depressant effect of dopamine were a nonspecific effect related to hyperventilation, infusion of dopamine would depress ventilation.

We also attempted to determine whether alpha or beta adrenergic receptors contribute to the ventilatory effects of dopamine. Responses to infusion of dopamine 
during hypoxia were observed after administration of the beta adrenergic blocker, propranolol, and during the infusion of the alpha adrenergic blocking agent, phentolamine.

\section{METHODS}

Eight healthy men, ages 19-25 yr, were studied. Approval of the Human Experimentation Committee (University of Iowa College of Medicine) and informed consent were obtained. A venous catheter was inserted in the basilic vein and connected to a syringe and Harvard pump (Harvard Apparatus Co., Inc., Millis, Mass.) for infusion of drugs. In three subjects another venous catheter was inserted for simultaneous infusion of phentolamine. A small polyethylene catheter was inserted percutaneously into the brachial artery. The catheter was connected to a pressure transducer for continuous recording of arterial pressure and to a syringe for obtaining blood samples. Heart rate was obtained from a cardiotachometer. $\mathrm{PO}_{2}$ and $\mathrm{PCO}_{2}$ of arterial blood were measured with an IL Ultramicro gas analyzer (Instrumentation Laboratory, Inc., Lexington, Mass.). The $\mathrm{O}_{2}$ electrode was calibrated at 0 and $84 \mathrm{~mm} \mathrm{Hg}$, and the $\mathrm{CO}_{2}$ electrode was calibrated at 35 and $70 \mathrm{~mm} \mathrm{Hg}$.

The subjects were studied while supine. They breathed through a one-way low resistance Douglas valve. Expired gas was measured in a Tissot spirometer which was adapted to allow continuous recording of volume. Percent $\mathrm{CO}_{2}$ of expired air was monitored continuously with a Beckman LB-1 $\mathrm{CO}_{2}$ analyzer (Beckman Instruments, Inc., Cedar Grove, N. J.). The gas removed by the $\mathrm{CO}_{2}$ analyzer was reintroduced into the expiratory line to avoid loss of volume.

Measurements were made before and during infusion of a "low dose" (0.5-2.5 $\mu \mathrm{g} / \mathrm{kg}$ per min) and a "high dose" (5 $\mu \mathrm{g} / \mathrm{kg}$ per min) of dopamine. Two subjects received an infusion of $10 \mu \mathrm{g} / \mathrm{kg}$ per min of dopamine. The order of infusion was low dose first in one-half of the subjects and high dose first in the other half of the subjects.

The infusions of dopamine were given while subjects breathed: $(a)$ room air; $(b)$ 10\% oxygen in nitrogen; $(c) 100 \%$ oxygen; and $(d) 5 \%$ carbon dioxide in $95 \%$ oxygen. The order of the four gas mixtures were randomized, and $10-20 \mathrm{~min}$ were allowed for recovery between each test period. The hypocapnia produced by breathing $10 \%$ oxygen was prevented by adding carbon dioxide to the inspired gas as described (17). After the flow rate of carbon dioxide was adjusted to maintain end-tidal $\mathrm{CO}_{2}$ at the control level, the rate was not altered during infusion of dopamine.

Before the measurements were made the subjects breathed the carbon dioxide in oxygen gas mixture for $10 \mathrm{~min}$ and the other gas mixtures for 4-5 min. The gas mixture was then continuously inhaled during the control measurements and during the infusion of the two doses of dopamine. Expired minute volume was then measured for $3 \mathrm{~min}$ and arterial blood gases were obtained in the middle of this period to provide control measurements. Dopamine was then infused for a total of $5 \mathrm{~min}$ while the subjects continued to breath the same gas mixture. During the first 2 min the maximum decrease in ventilation was determined from the slope of the line inscribed by the recording Tissot. Minute volume was then measured with the Tissot spirometer from the 3rd to 5th $\mathrm{min}$ of the infusion and averaged to give the "sustained" response of minute volume to dopamine infusion. This period from the 3 rd to 5 th min appears to be a steady-state response because there was no significant difference between minute volume measured at the 3rd, 4th, or 5th min. Arterial blood samples were obtained $\cong 4 \mathrm{~min}$ after the start of the infusion. After stopping the infusion of dopamine, 3 min were allowed for the drug effect to subside and then a second control measurement was made. The other dose of dopamine was then infused and the response was measured as described above.

In five subjects $8 \mathrm{mg}$ of propranolol was injected intravenously in $5 \mathrm{~min}$. This dose of propranolol blocks the ventilatory response to isoproterenol but does not change the ventilatory response to hypoxia (18). After $5 \mathrm{~min}$, subjects began breathing $10 \%$ oxygen (isocapnic hypoxia was achieved as described above) and the response to dopamine was observed. In three other subjects the response to dopamine during isocapnic hypoxia was measured during an intravenous infusion of phentolamine tosylate at a dose of $0.5 \mathrm{mg} / \mathrm{min}$. This dose of phentolamine blocks the decrease in ventilation produced by phenylephrine (18).

Measurements during infusion of dopamine were compared to measurements taken during the immediately preceding control period with a paired $t$ test. Responses to the different doses of dopamine were compared with a two-factor analysis of variance (19).

\section{RESULTS}

Normoxia. Dopamine depressed ventilation while subjects breathed room air (Table I). Minute ventilation decreased and arterial $\mathrm{PCO}_{2}$ increased during infusion of dopamine. During the control period, arterial $\mathrm{PaO}_{2}$ was $92 \pm 3.5 \mathrm{~mm} \mathrm{Hg}($ mean $\pm \mathrm{SE})$ and it decreased $10 \pm 2.9$ and $7 \pm 3.8 \mathrm{~mm} \mathrm{Hg}$ during low and high dose dopamine, respectively $(P<0.05$ for each dose).

Mean arterial pressure was $89 \pm 1.5 \mathrm{~mm} \mathrm{Hg}$ and did not change during either dose of dopamine. Heart rate was unchanged during low dose dopamine and increased from $60 \pm 2.8$ beats/min during the control period to $69 \pm 1.5$ beats $/ \mathrm{min}$ with high dose dopamine $(P<0.05)$.

Normocapnic hypoxia. In subjects breathing $10 \%$ oxygen, $\mathrm{PaO}_{2}$ decreased to $40 \pm 2.4 \mathrm{~mm} \mathrm{Hg}$ and minute volume increased almost twofold as compared to normoxia. However, $\mathrm{PaCO}_{2}$ was maintained unchanged by addition of $\mathrm{CO}_{2}$ to the inspired gas mixture.

Dopamine consistently depressed ventilation during hypoxia (Fig. 1, Table I). During infusion of dopamine there was significant decrease in minute ventilation and increase in $\mathrm{PaCO}_{2}$. The early response to infusion of dopamine always exceeded the sustained decrease in ventilation. The maximum decrease in minute ventilation observed with infusion of $5 \mu \mathrm{g} / \mathrm{kg}$ per min of dopamine was significantly greater than that observed with doses of 0.5 and $1.0 \mu \mathrm{g} / \mathrm{kg}$ per $\min (P<0.05)$.

Dopamine accentuated the degree of hypoxia, as a further reduction in $\mathrm{PaO}_{2}$ of $6 \pm 1.8 \mathrm{~mm} \mathrm{Hg}$ and $5 \pm 1.4$ $\mathrm{mm} \mathrm{Hg}$ was observed with infusion of low and high dose dopamine, respectively $(P<0.05)$. There was no change in arterial pressure with infusion of dopamine. Heart rate was $86 \pm 7.7$ beats/min during hypoxia, and did not change during low dose dopamine, and increased $4 \pm 1.4$ beats $/ \mathrm{min}$ with infusion of high dose dopamine.

Normocapnic hypoxia with alpha or beta adrenergic 
TABLE I

Effects of Dopamine on Ventilation

\begin{tabular}{|c|c|c|c|c|c|c|c|c|c|c|}
\hline & \multirow[b]{3}{*}{$\begin{array}{c}\text { Control } \\
1\end{array}$} & \multicolumn{5}{|c|}{ Minute ventilation } & & & & \\
\hline & & \multicolumn{2}{|c|}{ Dopamine-low dose } & \multirow[b]{2}{*}{$\begin{array}{c}\text { Control } \\
2\end{array}$} & \multicolumn{2}{|c|}{ Dopamine-high dose } & \multicolumn{4}{|c|}{$\mathrm{PCO}_{2}$} \\
\hline & & $\begin{array}{l}\text { Maximum } \\
\text { response }\end{array}$ & $\begin{array}{l}\text { Sustained } \\
\text { response }\end{array}$ & & $\begin{array}{l}\text { Maximum } \\
\text { response }\end{array}$ & $\begin{array}{l}\text { Sustained } \\
\text { response }\end{array}$ & $\begin{array}{c}\text { Control } \\
1\end{array}$ & $\begin{array}{l}\text { Dopamine } \\
\text { low dose }\end{array}$ & $\begin{array}{c}\text { Control } \\
2\end{array}$ & $\begin{array}{l}\text { Dopamine } \\
\text { high dose }\end{array}$ \\
\hline & \multicolumn{6}{|c|}{ liter/min } & \multicolumn{4}{|c|}{$m m H g$} \\
\hline Normoxia $(n=8)$ & $\begin{array}{r}7.5 \\
\pm 0.7\end{array}$ & $\begin{array}{l}-1.5 \ddagger \\
\pm 0.4\end{array}$ & $\begin{array}{l}-0.8 \ddagger \\
\pm 0.2\end{array}$ & $\begin{array}{r}8 .() \\
\pm 1 .()\end{array}$ & $\begin{array}{l}-1.5 \ddagger \\
\pm 0.3\end{array}$ & $\begin{array}{l}-0.4 \\
\pm 0.2\end{array}$ & $\begin{array}{r}34.3 \\
\pm 1.3\end{array}$ & $\begin{array}{l}+1.8 \$ \\
\pm 0.5\end{array}$ & $\begin{array}{r}37.4 \\
\pm 1.9\end{array}$ & $\begin{array}{l}+1.4 t \\
\pm 0.7\end{array}$ \\
\hline $\begin{array}{l}\text { Normocapnic hypoxia } \\
\quad(n=8)\end{array}$ & $\begin{array}{r}14.7 \\
\pm 1.0\end{array}$ & $\begin{array}{l}-3.6+ \\
\pm 0.9\end{array}$ & $\begin{array}{l}-1.4 \ddagger \\
\pm 0.3\end{array}$ & $\begin{array}{r}14.6 \\
\pm 1.2\end{array}$ & $\begin{array}{l}-6.1 \ddagger \\
\pm 0.8\end{array}$ & $\begin{array}{l}-2.0+ \\
\pm 0.3\end{array}$ & $\begin{array}{l}34.3 \\
\pm 1.7\end{array}$ & $\begin{array}{l}+1.5 \ddagger \\
\pm 0.7\end{array}$ & $\begin{array}{r}35.1 \\
\pm 1.5\end{array}$ & $\begin{array}{l}+3.6+ \\
\pm 0.6\end{array}$ \\
\hline $\begin{array}{l}\text { Hypercarbia and } \\
\text { hyperoxia }(n=5)\end{array}$ & $\begin{array}{r}24.1 \\
\pm 3.3\end{array}$ & $\begin{array}{l}+1.2 \\
\pm 1.0\end{array}$ & $\begin{array}{l}+0.9 \\
\pm 0.5\end{array}$ & $\begin{array}{r}2.5 .3 \\
\pm 2.9\end{array}$ & $\begin{array}{l}+2.1 \\
\pm 1.0\end{array}$ & $\begin{array}{l}+1.7 \\
\pm 0.8\end{array}$ & $\begin{array}{r}40.4 \\
\pm 2.2\end{array}$ & $\begin{array}{l}+0.2 \\
\pm 1.1\end{array}$ & $\begin{array}{r}41.2 \\
\pm 2.1\end{array}$ & $\begin{array}{l}-1.6 \\
\pm 1.2\end{array}$ \\
\hline Hyperoxia $(n=7)$ & $\begin{array}{r}8.4 \\
\pm 0.7\end{array}$ & $\begin{array}{l}-0.3 \\
\pm 0.3\end{array}$ & $\begin{array}{l}-0.2 \\
\pm 0.4\end{array}$ & $\begin{array}{r}8.4 \\
\pm 0.7\end{array}$ & $\begin{array}{l}-0.2 \\
\pm 0.2\end{array}$ & $\begin{array}{l}-0.2 \\
\pm 0.2\end{array}$ & $\begin{array}{r}32.9 \\
\pm 1.4\end{array}$ & $\begin{array}{l}+0.4 \\
\pm 0.5\end{array}$ & $\begin{array}{r}35.2 \\
\pm 2.4\end{array}$ & $\begin{array}{l}-0.3 \\
\pm 0.4\end{array}$ \\
\hline
\end{tabular}

* The maximum response and sustained response refer to the change in minute ventilation during infusion of dopamine compared to the preceding control value. Dopamine-low dose refers to a dose of $0.5-2.5 \mu \mathrm{g} / \mathrm{kg}$ per min, and dopamine-high dose refers to an infusion of $5 \mu \mathrm{g} / \mathrm{kg}$ per min dopamine. Values are expressed as mean $\pm \mathrm{SE}$.

$\$$ Indicates that response represents a statistically significant change from the control value $(P<0.05)$.

blockade. Administration of phentolamine did not alter the ventilatory response to dopamine during hypoxia in three subjects. Minute ventilation during the

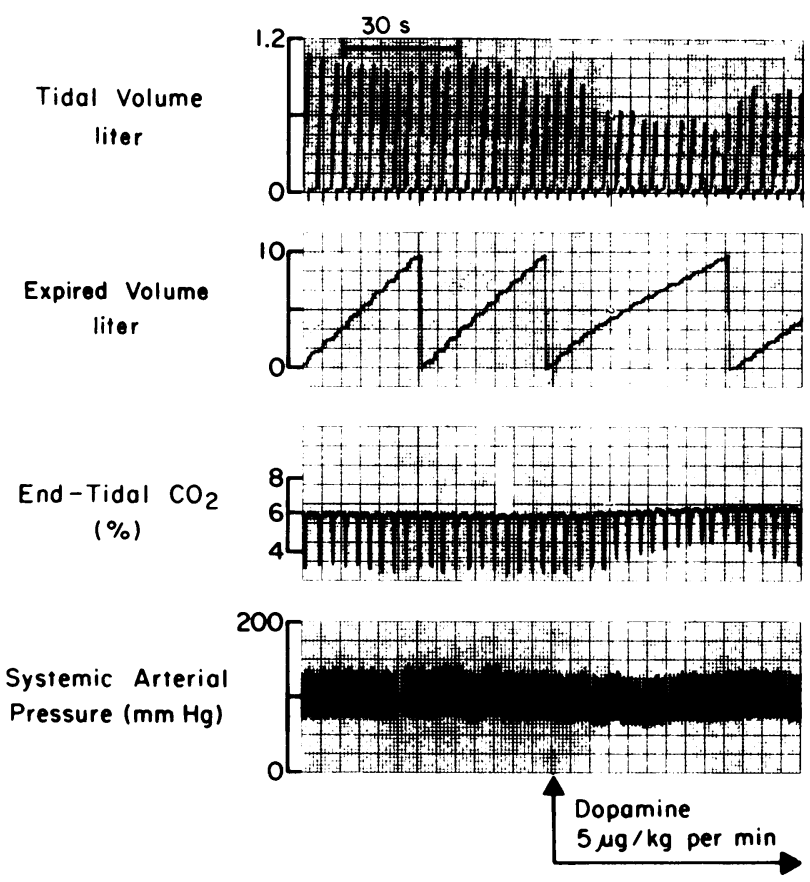

Figure 1 The ventilatory response to infusion of dopamine during nomocapnic hypoxia. Inspiratory How was measured with a Fleisch pnemotachograph and integrated to give tidal volume for purposes of illustration. Expired volume was recorded directly from a Tissot spirometer. control period was $15.4 \pm 1.3$ liter $/ \mathrm{min}$ and $\mathrm{PA}_{\mathrm{CO}_{2}}$ was $34 \pm 0.8 \mathrm{~mm} \mathrm{Hg}$. The sustained decreases in minute ventilation with low and high dose dopamine were $-1.0 \pm 0.2 \mathrm{liter} / \mathrm{min}$ and $-2.4 \pm 0.5 \mathrm{liter} / \mathrm{min}$ respectively before phentolamine, and $-1.0 \pm 0.5$ liter $/ \mathrm{min}$ and -2.4 \pm 0.1 liter $/ \mathrm{min}$ after phentolamine. The corresponding changes in $\mathrm{PaCO}_{2}$ were $+0.3 \pm 0.7 \mathrm{~mm} \mathrm{Hg}$ and $+3.7 \pm 0.7$ $\mathrm{mm} \mathrm{Hg}$ before phentolamine and $+0.7 \pm 0.3 \mathrm{~mm} \mathrm{Hg}$ and $+2.3 \pm 0.9 \mathrm{~mm} \mathrm{Hg}$ after phentolamine.

Similarly, beta adrenergic blockade in five subjects did not change the ventilatory response to dopamine during hypoxia. Minute ventilation during the control period was $13.4 \pm 0.9$ liter $/ \mathrm{min}$ and $\mathrm{PaCO}_{2}$ was $35.8 \pm 1.3$ $\mathrm{mm} \mathrm{Hg}$. The sustained decreases in minute ventilation with low and high dose dopamine were $-1.8 \pm 0.4$ liter/ $\mathrm{min}$ and $-1.9 \pm(0.3 \mathrm{liter} / \mathrm{min}$ respectively before propranolol, and $-1.9 \pm 0.3 \mathrm{liter} / \mathrm{min}$ and $-1.7 \pm 0.2$ liter/ min after propranolol. The corresponding changes in $\mathrm{PaCO}_{2}$ were $+2.7 \pm 0.9 \mathrm{~mm} \mathrm{Hg}$ and $+3.6 \pm 0.9 \mathrm{~mm} \mathrm{Hg}$ before propranolol and $+2.7 \pm 0.7 \mathrm{~mm} \mathrm{Hg}$ and +3.2 $\pm 0.9 \mathrm{~mm} \mathrm{Hg}$ after propranolol.

There was no change in arterial pressure with administration of dopamine after either blocker. Heart rate did not change during infusion of dopamine after the adrenergic blockers, except an increase of $14 \pm 2.0$ beats/min was observed with administration of high dose dopamine during phentolamine.

Hypercarbia and hyperoxia. Subjects breathing 5\% carbon dioxide in 95\% oxygen showed the expected increase in $\mathrm{PaCO}_{2}$, increase in $\mathrm{PaO}_{2}$ to $>400 \mathrm{~mm} \mathrm{Hg}$ in all subjects, and marked increase in minute ventilation (Table I). There were no significant changes in 
$\mathrm{PaCO}_{2}$ or minute ventilation during the administration of dopamine. Heart rate and arterial pressure did not change with dopamine infusion.

Hyperoxia. While the subjects breathed $100 \%$ oxygen, there was no change in minute volume or $\mathrm{PaCO}_{2}$ during infusion of dopamine (Table I). Arterial $\mathrm{PO}_{2}$ was $>400 \mathrm{~mm} \mathrm{Hg}$ in all subjects. Mean arterial pressure was $96 \pm 3.0 \mathrm{~mm} \mathrm{Hg}$ and increased $4.5 \pm 0.5 \mathrm{~mm} \mathrm{Hg}$ $(P<0.05)$ during infusion of the low dose of dopamine, but did not change during infusion of high dose dopamine. The heart rate was $64 \pm 5.5$ beats $/ \mathrm{min}$ and increased $6.6 \pm 2.4$ beats/min during infusion of the high dose of dopamine.

Response to dopamine $10 \mu \mathrm{g} / \mathrm{kg}$ per min. Dopamine was infused at a rate of $10 \mu \mathrm{g} / \mathrm{kg}$ per min in two subjects during normoxia and hypoxia. During normoxia, infusion of dopamine tended to increase minute volume (0.1 and 2.0 liter $/ \mathrm{min}$ ) and $\mathrm{PaCO}_{2}$ did not change. During hypoxia infusion of dopamine produced a sustained decrease in minute ventilation $(-1.1$ and -0.5 liter/min) and increase in $\mathrm{PaCO}_{2}(6$ and $2 \mathrm{~mm} \mathrm{Hg})$. After administration of propranolol, infusion of dopamine in hypoxic subjects decreased minute ventilation (2.1 liter/min in both subjects) and increased $\mathrm{PaCO}_{2}(6$ and $3 \mathrm{~mm} \mathrm{Hg}$ ).

\section{DISCUSSION}

The present studies indicate that infusion of low doses of dopamine suppresses ventilation in man. When arterial chemoreceptor activity was increased by hypoxia, dopamine depressed ventilation. During normoxia, infusion of dopamine produced less suppression of ventilation. When arterial chemoreceptors were suppressed by breathing $100 \%$ oxygen, infusion of dopamine did not change ventilation. This relationship between the degree of suppression of ventilation and the level of chemoreceptor activity suggests that the depressant effect of dopamine on ventilation is mediated through an effect on the chemoreceptor reflex.

We considered the possibility that dopamine might depress ventilation in a nonspecific manner, whenever hyperventilation is present. To investigate this possibility, the ventilatory effect of infusion of dopamine was observed during hyperventilation produced by breathing an increased concentration of carbon dioxide in oxygen. Hypercarbia stimulates ventilation predominantly through an effect on the central medullary chemoreceptors (16) but also tends to stimulate the carotid bodies (20). When hyperoxia is combined with hypercarbia, the subjects hyperventilate while the peripheral chemoreceptors are suppressed. It has been shown that at a high level of Po. minimal despite hypercapnia (20). Administration of dopamine under these circumstances did not suppress ventilation. This observation indicates that the action of dopamine is not dependent primarily on a high level of ventilation nor due to suppression of central chemoreceptors. This finding supports the conclusion that suppression of ventilation by dopamine is mediated through an action on the peripheral chemoreceptor reflex.

Stimulation of central dopamine receptors, by intracisternal injection of apomorphine (21), depresses ventilation. The possibility that our findings are the result of a central action of dopamine, perhaps on central connections of the chemoreceptor reflex, should be considered. This possibility seems unlikely, because the blood-brain barrier minimizes the access of dopamine into the brain (22). Furthermore, dopamine did not alter the response of central chemoreceptors to hypercapnia, which suggests that intravenously administered dopamine may not have important effects centrally. Nevertheless it seems appropriate to emphasize that, although these studies indicate that dopamine inhibits the chemoreceptor reflex, it is not possible to determine the precise locus of action of dopamine.

During the infusion of dopamine, a two-phase ventilatory response was observed. During the maximum suppression of ventilation produced by infusion of $5 \mu \mathrm{g} / \mathrm{kg}$ per min of dopamine in hypoxic subjects, ventilation decreased from about $14 \mathrm{liter} / \mathrm{min}$ to $\cong 8$ liter/min. When chemoreceptor activity was minimal, during hyperoxia, the minute volume was also about 8 liter/min. The depression of ventilation by dopamine to this level suggests that dopamine transiently abolished the increased peripheral chemoreceptor drive to ventilation during hypoxia. The second phase of the response was observed during the $3 \mathrm{rd}-5$ th min of dopamine infusion. During this time the minute volume was lower than during the control period but higher than the levels observed during the transient maximum depression of ventilation. The increase in ventilation from the level of maximal suppression to the sustained level may be accounted for in part by the increase in $\mathrm{PaCO}_{2}$ with increased central chemoreceptor drive to ventilation.

Dopamine stimulates alpha, beta, and dopaminergic receptors (23). The depressant effect on ventilation of low doses of dopamine was unaltered after beta adrenergic receptor blockade. Infusion of phentolamine, at a dose that blocks the cardiovascular and ventilatory effects of phenylephrine (18), did not alter the ventilatory response to infusion of low doses of dopamine. However, high doses of alpha blockers may be required to block alpha adrenergic receptors in chemoreceptors (10), so that our studies do not exclude the possibility that the effect of dopamine is mediated through alpha receptors. We did not give agents 
capable of producing dopaminergic receptor blockade because we were concerned about the safety of their experimental use in normal humans. Our findings during infusion of phentolamine, in addition to the observation that dopaminergic effects predominate at low doses of dopamine and alpha adrenergic effects predominate at high doses (23), suggest that the depressant effect on ventilation of low doses of dopamine may be mediated by dopaminergic receptors.

Dopamine has been observed to stimulate ventilation in man (24). Infusion of dopamine in two subjects at doses of 10 and $12 \mu \mathrm{g} / \mathrm{kg}$ per min produced an increase in ventilation whereas four subjects who received doses ranging from 5 to $8 \mu \mathrm{g} / \mathrm{kg}$ per min had no change in ventilation (24). Lower doses of dopamine were not used and responses were not observed during stimulation of chemoreceptors by hypoxia. In our two subjects given an infusion of $10 \mu \mathrm{g} / \mathrm{kg}$ per min of dopamine, ventilation increased while they breathed room air and decreased only slightly during hypoxia. After beta receptor blockade, infusion of 10 $\mu \mathrm{g} / \mathrm{kg}$ per min of dopamine to hypoxic subjects produced a depression of ventilation similar to that observed at a dose of $5 \mu \mathrm{g} / \mathrm{kg}$ per min of dopamine. The observation that ventilation is depressed by infusion of low doses and stimulated by high doses of dopamine suggests that the effects of dopamine on the chemoreceptor reflex may be mediated by more than one receptor. At low doses of dopamine, a depressant effect on the chemoreceptor reflex may be produced by stimulation of dopaminergic or alpha adrenergic receptors. At high doses of dopamine, stimulation of beta adrenergic receptors may increase ventilation (18) and mask the depressant effects observed at lower doses.

Arterial $\mathrm{PO}_{2}$ decreased in response to infusion of dopamine during normoxia and hypoxia. The decrease in $\mathrm{PO}_{2}$ was larger than that which would be expected from the degree of hypoventilation. From the alveolar gas equation (25) if the respiratory exchange ratio is assumed to be 0.8 , the increase in $\mathrm{PCO}_{2}$ which was observed would be expected to reduce $\mathrm{PO}_{2}$ by $2-4.5$ $\mathrm{mm} \mathrm{Hg}$; the observed decrease in $\mathrm{PO}_{2}$ was 5-10 $\mathrm{mm} \mathrm{Hg}$. It is possible that the decrease in $\mathrm{PO}_{2}$ during infusion of dopamine is due in part to pulmonary vasodilation and shunting. Based on studies in patients with heart failure, it has been suggested that dopamine may open arteriovenous anastomoses, resulting in an increase in ventilation-perfusion inequality (26). Other studies suggest that the increase in pulmonary shunting is secondary to the increase in cardiac output, with a passive increase in blood flow to poorly ventilated regions of the lung (27). Although pulmonary shunting has not been reported during infusion of dopamine in normal subjects, it may contribute to the decrease in $\mathrm{PO}_{2}$ which we observed in response to dopamine. We should point out that dopamine-induced shunting and hypoxia would increase ventilation and tend to mask the depressant effect of low doses of dopamine on the chemoreceptor reflex. Therefore the magnitude of the effect of dopamine in inhibition of the chemoreceptor reflex may be underestimated in the present studies.

Dopamine has been observed to produce different effects on chemoreceptors in different species (12). In cats dopamine depresses ventilation and decreases carotid chemoreceptor neural output $(12,13)$. In dogs dopamine stimulates ventilation $(12,14)$, but the response to dopamine has not been observed during stimulation of chemoreceptors with hypoxia. Our findings indicate that in man, as in cats, dopamine depresses the chemoreceptor reflex.

Several investigators have suggested that dopamine may be released in the carotid body during hypoxia and decrease the sensitivity of chemoreceptors (8-11). An alternate theory is that chemoreceptor fibers discharge tonically, that the discharge rate is reduced by a continuous high rate of secretion of dopamine in the carotid body, and that reduction in the secretion of dopamine during hypoxia results in increased neural discharge (28). Our study does not offer insight into the validity of either theory, but the findings are compatible with the hypothesis that dopamine is an inhibitory neurotransmitter in the carotid body of man.

In a previous study we reported that norepinephrine and isoproterenol increase ventilation in humans through a beta adrenergic effect on the chemoreceptor reflex (18). In contrast, results of this study suggest that low doses of dopamine decrease ventilation through an effect on the chemoreceptor reflex. it is possible that both neurotransmitters may be physiologically important modulators of chemoreceptor function and that they mediate a reciprocal function. A similar relationship between norepinephrine and dopamine has been proposed to exist in the central nervous system (29).

\section{ACKNOWLEDGMENTS}

We wish to thank Janice Tracy for her technical assistance, Robert Woolson for his assistance with the statistical analysis, and Patti Young for her preparation of the manuscript. We also thank Jay Farber, Allyn Mark, and Craig Bainbridge for their discussion and criticisms.

This work was supported by Research Career Development Award HL-00041, research grant HL-16066, and program project grant HL-14388 from the National Heart and Lung Institute, and by research grant MRIS 3546 from the Veterans Administration.

\section{REFERENCES}

1. Wasserman, K., and B. J. Whipp. 1976. The carotid bodies and respiratory control in man. In Morphology and Mech- 
anisms of Chemoreceptors. A. S. Paintal, editor. Vallabhbhai Patel Chest Institute, University of Delhi Press, Delhi. 156-175.

2. Steele, R. H., and H. Hinterberger. 1972. Catecholamines and 5-hydroxytryptamine in the carotid body in vascular, respiratory, and other diseases. J. Lab. Clin. Med. 80: 63-70.

3. Niemi, M., and K. Ojala. 1964. Cytochemical demonstration of catecholamines in the human carotid body. Nature (Lond.). 203: 539-540.

4. Chiocchio, S. R., A. M. Biscardi, and J. H. Tramezzani. 1966. Catecholamines in the carotid body of the cat. Nature (Lond.). 212: 834-835.

5. Chiocchio, S. R., M. P. King, L. Carballo, and E. T. Angelakos. 1971. Monoamines in the carotid body cells of the cat. J. Histochem. Cytochem. 19: 621-626.

6. Dearnaley, D. P., M. Fillenz, and R. I. Woods. 1968. The identification of dopamine in the rabbit's carotid body. Proc. R. Soc. (Lond.). B. Biol. Sci. 170: 195-203.

7. Hellstrom, S., I. Hanbauer, and E. Costa. 1976. Selective decrease of dopamine content in rat carotid body during exposure to hypoxic conditions. Brain Res. 118: 352-355.

8. McDonald, D. M., and R. A. Mitchell. 1975. The innervation of glomus cells, ganglion cells and blood vessels in the rat carotid body: a quantitative ultrastructural analysis. J. Neurocytol. 4: 177-230.

9. Mitchell, R. A., and D. A. McDonald. 1975. Adjustment of chemoreceptor sensitivity in the cat carotid body by reciprocal synapses. In The Peripheral Arterial Chemoreceptors. M. J. Purves, editor. Cambridge University Press, London. 269-291.

10. Sampson, S. R. 1975. Pharmacology of feedback inhibition of carotid body chemoreceptors in the cat. In The Peripheral Arterial Chemoreceptors. M. J. Purves, editor. Cambridge University Press, London. 207-220.

11. Sampson, S. R., G. Nicolaysen, and R. A. Jaffe. 1975. Influence of centrifugal sinus nerve activity on carotid body catecholamines: microphotometric analysis of formaldehyde-induced fluorescence. Brain Res. 85: 437 446.

12. Black, A. M. S., J. H. Comroe, Jr., L. Jacobs. 1972. Species difference in carotid body response of cat and dog to dopamine and serotonin. Am. J. Physiol. 223: 1097-1102.

13. Sampson, S. R. 1972. Mechanism of efferent inhibition of carotid body chemoreceptors in the cat. Brain Res. 45: $266-270$.

14. Jacobs, L., and J. H. Comroe, Jr. 1968. Stimulation of the carotid chemoreceptors of the dog by dopamine. Proc. Natl. Acad. Sci. 54: 1187-1193.

15. Dejours, P. 1962. Chemoreflexes in breathing. Physiol. Rev. 42: 335-358.

16. Leusen, I. 1972. Regulation of cerebrospinal fluid composition and reference to breathing. Physiol. Rev. 52: 1-56.

17. Heistad, D. D., and R. C. Wheeler. 1970. Effect of acute hypoxia on vascular responsiveness in man. J. Clin. Invest. 49: 1252-1265.

18. Heistad, D. D., R. C. Wheeler, A. L. Mark, P. G. Schmid, and F. M. Abboud. 1972. Effects of adrenergic stimulation on ventilation in man. J. Clin. Invest. 51: 1468-1475.

19. Huntsberger, D. V., and P. E. Leaverton. 1970. Statistical Inference in Biomedical Sciences. Allyn \& Bacon, Inc., Boston.

20. Hornbein, T. F. 1968. The relation between stimulus to chemoreceptors and their response. In Arterial Chemoreceptors. R. W. Torrance, editor. Blackwell Scientific Publications Ltd., Oxford, England. 65-78.

21. Bolme, P., K. Fuxe, T. Hokfelt, and M. Goldstein. 1977. Studies on the role of dopamine in cardiovascular and respiratory control: central versus peripheral mechanisms. Adv. Biochem. Psychopharmacol. 16: 281-290.

22. Oldendorf, W. H. 1971. Brain uptake of radiolabeled amino acids, amines, and hexoses after arterial injection. Am. J. Physiol. 221: 1629-1639.

23. Goldberg, L. I. 1972. Cardiovascular and renal actions of dopamine: potential clinical applications. Pharmacol. Rev. 24: 1-29.

24. Horwitz, D., S. M. Fox, and L. I. Goldberg. 1962. Effects of dopamine in man. Circ. Res. 10: 237-243.

25. Tenny, S. M., and T. W. Lamb. 1965. Physiological consequences of hypoventilation and hyperventilation. In Handb. Physiol. 2(Sect. 3 Respiration): 979-10(18.

26. Huckauf, H., B. Ramdohr, and R. Schroder. 1976. Dopamine induced hypoxemia in patients with left heart failure. Int. J. Clin. Pharmacol. Biopharm. 14: 217-224.

27. Mulroy, M. F., and H. B. Fairley. 1977. Effect of dopamine on intrapulmonary shunt fraction and oxygen transport in acute pulmonary failure. Am. Rev. Respir. Dis. 115: $S-143$.

28. Osborne, M. P., and P. J. Butler. 1975. New theory for receptor mechanism of carotid body chemoreceptors. Nature (Lond.). 254: 701-703.

29. Antelman, S. M., and A. R. Caggiula. 1977. Norepinephrine-dopamine interactions and behavior. Science (Wash. D. C.). 195: 646-653. 